\title{
COMPARISON BETWEEN FIRE RESISTANCE LIGHTWEIGHT BRICK AND FIRE RESISTANCE RED BRICK
}

\author{
Aventi, Ir. MT \\ Madya Researcher - Research Institute for Human Settlements - Public Works Ministry \\ Jalan Panyaungan - Cileunyi Wetan - Kabupaten Bandung - Indonesia
}

\begin{abstract}
At this moment, lightweight brick are widely used, considering lightweight brick is a modern development of producing conblock that usual and always done by society.

Lightweight brick is a kind of brick for building was made from silica sand which is resistant to heat and can reduce risk fire. Lightweight brick is building component that produced by process technology modern using modern machines through process aeration and autoclave to produce high quality products, lightweight, strength, waterproof, fireproof, and soundproof.
\end{abstract}

Lightweight bricks designed by ergonomic and accurate which makes it more efficient in the use of cement compared with conventional construction and can give more value to the building.

The process of aeration are homogeneous and controlled by computerized, produce lightweight brick that have highest pressure strength but lightest in its class. These products have started to use at building and housing.

Lightweight brick can directly given mortar without plastered beforehand, by using specific kind of cement. To use it, this cement only mixed with water. Lightweight bricks generally has size $60 \mathrm{~cm} \mathrm{x}$ $20 \mathrm{~cm}$ with thickness $8-10 \mathrm{~cm}$.

Red brick is a kind of brick for building was made from clay that shaped then burned with high temperature so become dry completely, hardened and reddish colored. Housing or building that have walls made of red brick will be more comfortable, stronger, durable, and resistant to heat.

Red brick have length $17-23 \mathrm{~cm}$, width $7-11 \mathrm{~cm}$, thick $3-5 \mathrm{~cm}$, and average weight $3 \mathrm{~kg}$ per peace.

The purpose of this research is to find out how differences between the usage of lightweight brick with the usage of red brick as building component in make housing or building.

Also to know how far lightweight brick's strength compared with red brick's strength, in its ability to fire resistance level.

So the society or government which built using lightweight brick or red brick, can get benefit by using building components in make housing or building that have fire resistance level, so that housing or building can avoid from fire hazard, which lately often occur in large city, due to climate change.

The benefits of this research is to get comparison value testing result fire resistance level from lightweight brick or red brick as building component, which is more resistant to fire resistance level. 
And to get building components that have high fire resistance level, so housing or building that have built using that building component can avoid of fire hazard.

The scope of this research consists of : (a) To find out the advantages and disadvantages of lightweight brick and red brick ; (b) To know how physical properties and chemical properties of lightweight brick and red brick, so can be used as fire resistant building component ; (c) To know the utilization of lightweight brick and red brick, as building component in make housing or building ; (d) To know burning temperature in furnace at fire resistance test to lightweight brick and red brick ; and (e) To compare fire resistance level that was produced with standard requirements.

Keywords: fire resistance, lightweight brick, red brick.

\section{INTRODUCTION}

\section{Lightweight Brick}

Lightweight brick or often called hebel or celcon made by using machines in factory. This brick quite light, smooth and have good flatness level. Lightweight brick was invented in order to make lighter load structure of building construction, accelerate construction, and minimize waste material that occur during process construction wall.

Mixture composition of lightweight brick, consist of sand kwarsa, cement, lime, gypsum, water, and aluminum pasta as accelerate material (air filler chemically). After mixture was mixed perfectly, will expand as lpng as $7-8$ hours. For construction at wall width $1 \mathrm{~m}^{2}, \pm$ need 8 pieces lightweight brick.

Specification lightweight brick :

- Dry density : $520 \mathrm{~kg} / \mathrm{m}^{3}$.

- Normal density $650 \mathrm{~kg} / \mathrm{m}^{3}$

- $\quad$ Pressure test $>4,0 \mathrm{~N} / \mathrm{mm}^{2}$.

- Thermal conductifity 0,14 $\mathrm{W} / \mathrm{mK}$

- Thick space between lightweight brick $3 \mathrm{~mm}$.

- Fire resistance 4 hours.

- Amount per $1 \mathrm{~m}^{2}: 22-26$ pieces with construction waste, or $8-9$ pieces without construction waste.
Advantages lightweight brick :

- Have size and quality that homogeny so can decrease neat wall.

- $\quad$ No need space between lightweight brick that thick so save usage mortar.

- Lighter $50 \%$ than red brick so minimize load of structure.

- $\quad$ Easy to handling.

- The construction is faster than red brick, because have bigger size and lighter.

- Not required thick plastering, generally determined only $2.5 \mathrm{~cm}$. Save plastering and space until $75 \%$ because its size larger than red brick.

- Water proof, walls not easy to moist and quick to dry.

- $\quad$ Sound proof, so soundness level is low.

- High pressure strength.

- $\quad$ Have good durability against earthquake. 
- Heat insulation, make temperature indoor so stable.

- Fire resistance

- Environmentally because $70 \%$ the material is air.

- Generally have size $60 \mathrm{~cm}$ x $20 \mathrm{~cm}$ with thickness $8-$ $10 \mathrm{~cm}$.

Disadvantages lightweight brick :

- Need specific skill to construction, because if not its impact to be seen.

- $\quad$ The size is middle, throw remaining quite a lot.

- Have specific adhesive. Generally is cement instant, mortar.

- If exposed to water, hence to become thoroughly dried out needed more time of red brick.

- If forced plastered before dry then shall arise yellow spotting on plastering.

- $\quad$ Price relatively more expensive than red brick.

- Almost difficult to get it. Only large material store that sells lightweight brick in large volume $\left(\mathrm{m}^{3}\right)$.

\section{Red Brick}

$1 \mathrm{~m}^{2}$ wall, if using red brick sized $23 \mathrm{~cm}$ x $17 \mathrm{~cm} \mathrm{x}$ $5 \mathrm{~cm}$, need \pm 70 pieces red brick. Raw materials was needed into space between red brick is cement and sieve sand. At the time of construction not requiring specific adhesive, at wall watertight required a mixture 1 cement : 2 sand or 1 cement : 3 sand. Meanwhile, at wall not watertight can use a mixture 1 cement : 4 sand to 1 cement : 6 sand.

Specifications red brick :
- $\quad$ Dry specific gravity $(\rho)$ : $1500 \mathrm{~kg} / \mathrm{m}^{3}$.

- Normal specific gravity ( $\rho): 2000 \mathrm{~kg} / \mathrm{m}^{3}$.

- $\quad$ Pressure strength : 2.5 $25 \mathrm{~N} / \mathrm{mm}^{2}$ (SII-0021, 1978).

- Thermal conductivity : $0.380 \mathrm{~W} / \mathrm{mK}$.

- $\quad$ Thick space between red brick : 20 - $30 \mathrm{~mm}$.

- Fire resistance : 2 hours.

- The number of necessity red brick per $1 \mathrm{~m}^{2}: 70$ 72 pieces with construction waste, or 30 35 pieces without construction waste.

Advantages red brick :

- Not requiring specific skill to put up.

- $\quad$ Small size, easy to handling.

- $\quad$ Easy to build, small size.

- $\quad$ Cheap price.

- Easy to get it.

- Unnecessary specific adhesive.

- Heat-resistant.

- Waterproof, so rare seepage water on the wall due to rain.

- Crack relative infrequent.

- $\quad$ Strong and durable.

Disadvantages red brick :

- Takes time and difficult to make masonry being tidy.

- Absorbing heat in summer time and absorbing cold in winter, so room 
temperature could not

conditioned or unstable.

- Difficult to get masonry that quite neat, required plastering that thick enough to produce a wall that quite plain.

- Time to construction was longer than the other material for wall.

- Heavy, so overburden structure that shore up.

\section{METHODOLOGY}

\section{Apparatus}

- Vertical furnace and small furnace, made from steel plate and the inside part covered by mulite, steel resistance to fire, material isolation, mortar, and so on.

- An instrument to laying sample shaped wheeled truck equipped 4 pieces clamps sample in furnace.

- An instrument burner consist of 4 pieces burner. Fuel used gases and kerosene.

- Coolant furnace made of steel no rust, installed on the upper part of furnace.

- $\quad$ Pump with motor $0,2 \mathrm{~kW}$.

- Fan with air flow $12 \mathrm{~m}^{3}$ /minute, static pressure $700 \mathrm{~mm}$ column of water, with motor $3,7 \mathrm{~kW}$.

- Fan reckoner type turbo fan air flow $65 \mathrm{~m}^{3}$ /minute, static pressure 40 mm column of water, with motor $2,2 \mathrm{~kW}$.
- Chimney made of steel plates that equipped paint fire proof, diameter 300 $\mathrm{mm}$, high $1.000 \mathrm{~mm}$.

- Chimney door shaped butterflies wing installed in the middle of chimney, the benefit to air circulation system.

- Oil tank made of steel plate with diameter 760 $\mathrm{mm}$, high $1.200 \mathrm{~mm}$, equipped with volumenometer.

- Temperature recorder with 6 pieces pen, distance measurement of temperature can be arranged from $0{ }^{\circ} \mathrm{C}-300$ ${ }^{\circ} \mathrm{C}, 0{ }^{\circ} \mathrm{C}-600{ }^{\circ} \mathrm{C}, 0{ }^{\circ} \mathrm{C}-$ $1.200{ }^{\circ} \mathrm{C}$.

- The speed of turnaround paper graph : 12,$5 ; 25$; $75 ; 150 ; 375$; and 750 $\mathrm{mm} /$ hour.

- Thermocouple refractory in diameter $10 \mathrm{~mm}$, length $2,000 \mathrm{~mm}$, installed in the range each end of heat of $30 \mathrm{~mm}$ thermocouple from the surface of sample, while distance installation thermocouple on the walls of furnace installed parallel not less than 100 $\mathrm{mm}$.

- Thermocouple to measure temperature surface at unexposed surface sample, diameter $0,84 \mathrm{~mm}$ length $4.000 \mathrm{~mm}$.

- Control panel made of steel plates, functioned to set burning. 
Procedure

- $\quad$ Before testing, first sample dried in a room with good ventilated.

- $\quad$ Sample after constructed on truck wheeled, burned in furnace equipped with 5 thermocouple installed dispersed so obtained average temperature. Burning test ways of sample arranged in accordance with component function in building : walls are burned on one surface with an upright direction /vertical.

- Standard temperature curve :

- $\quad 760{ }^{\circ} \mathrm{C}$ at the first 15 minutes.

- $\quad 840{ }^{\circ} \mathrm{C}$ at the next 30 minutes.

- $880{ }^{\circ} \mathrm{C}$ at the next 40 minutes.

- $895{ }^{\circ} \mathrm{C}$ at the next 50 minutes.

- $\quad 905{ }^{\circ} \mathrm{C}$ at the next 50 minutes.

- $\quad 915{ }^{\circ} \mathrm{C}$ at the next 55 minutes.

- $\quad 925{ }^{\circ} \mathrm{C}$ at the next 1 hours.

- $\quad 1010{ }^{\circ} \mathrm{C}$ at the next 2 hours.

- $\quad 1050{ }^{\circ} \mathrm{C}$ at the next 3 hours.

- Measurement burning temperature at sample, both given load and not given load, done every 5 minutes.

\section{TESTING RESULTS}

Sample lightweight brick were made and then put up the thermocouple for measure temperature surface construction lightweight brick.

Construction lightweight brick that tested is used for wall. Dimension one lightweight brick : length $600 \mathrm{~mm} \mathrm{x}$ width $200 \mathrm{~mm} \mathrm{x}$ thick $100 \mathrm{~mm}$, construction wall lightweight brick : width 1050 mm x length $1060 \mathrm{~mm} x$ thick $100 \mathrm{~mm}$.

Temperature air ambient at the beginning of testing is $23.2{ }^{\circ} \mathrm{C}$.

Furnace temperature was arranged so follows standard curve time - temperature according to SNI $1741-2008$

Furnace temperature were measured by five thermocouple TC \#1 - TC \#5 that separated in furnace and placed $300 \mathrm{~mm}$ from sample surface.

Unexposed surface temperature of sample were measured by five thermocouple TC\#6, \#7, \#8, \#9 and \#10 that put up exact way at wall surface of sample that unexposed by fire.

Fire test was conduct as long as 170 minute.

Average furnace temperature was showed at Table 1 and Graph 1.

At the end of test, average furnace temperature achieved $1047^{\circ} \mathrm{C}$. 
Table 1. Average Furnace Temperature

\begin{tabular}{|c|c|c|}
\hline Minute & $\begin{array}{l}\text { Average Furnace Temperature } \\
{ }^{\circ} \mathrm{C}\end{array}$ & $\begin{array}{l}\text { Standard Furnace Temperature } \\
\text { SNI } 1741-2008\end{array}$ \\
\hline 0 & 31 & 20 \\
\hline 10 & 657 & 678 \\
\hline 20 & 799 & 781 \\
\hline 30 & 844 & 842 \\
\hline 40 & 892 & 885 \\
\hline 50 & 915 & 918 \\
\hline 60 & 930 & 945 \\
\hline 70 & 939 & 968 \\
\hline 80 & 967 & 988 \\
\hline 90 & 987 & 1006 \\
\hline 100 & 999 & 1022 \\
\hline 110 & 1012 & 1036 \\
\hline 120 & 1012 & 1049 \\
\hline 130 & 1017 & 1061 \\
\hline 140 & 1025 & 1072 \\
\hline 150 & 1031 & 1082 \\
\hline 160 & 1038 & 1092 \\
\hline 170 & 1047 & 1101 \\
\hline
\end{tabular}

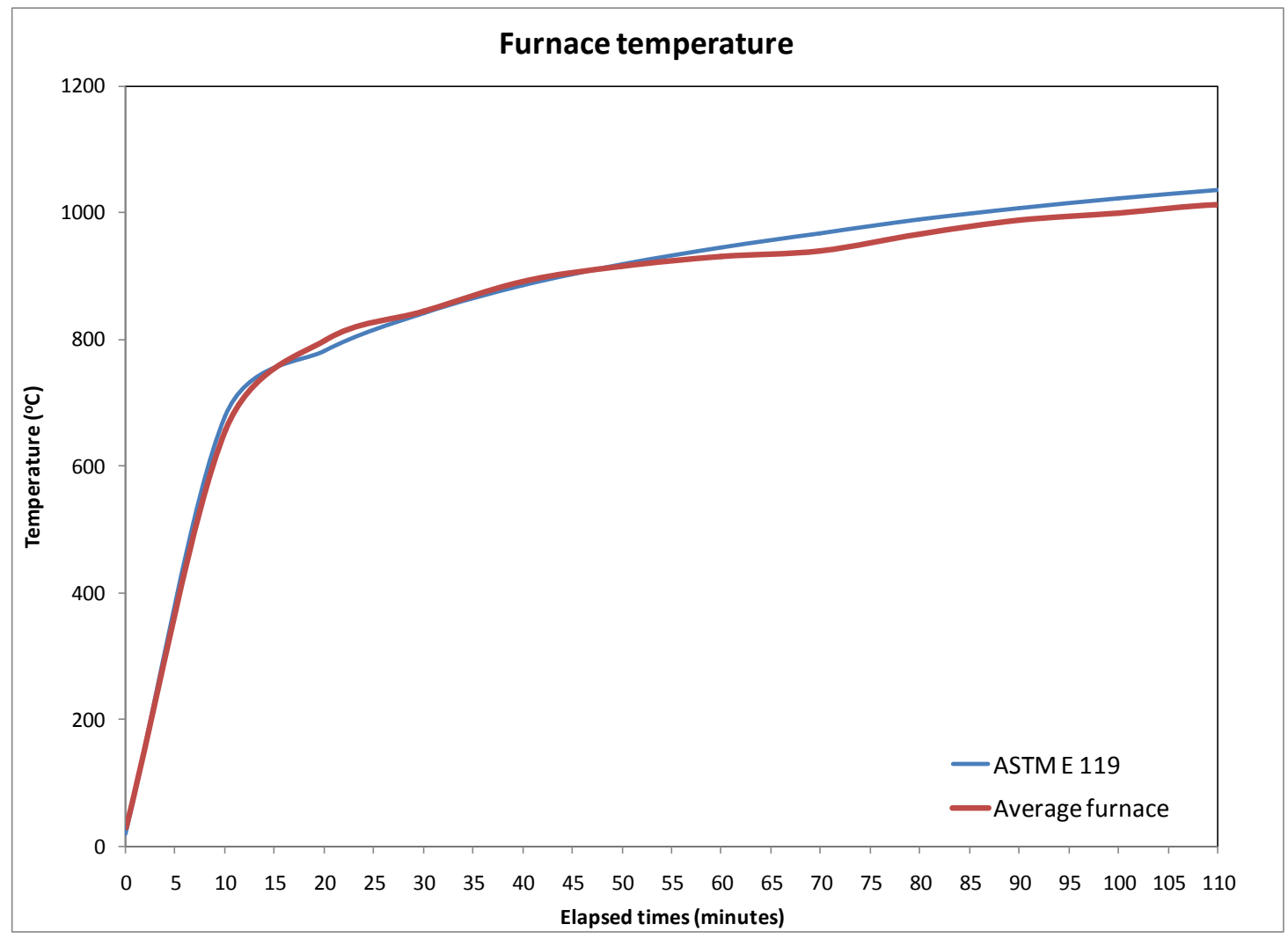

Graph 1 Unexposed surface temperature was showed at Table 2 and Graph 2. 
Table 2. Temperature at Surface Sample

\begin{tabular}{|c|c|c|c|c|c|c|c|c|}
\hline Minute & $\begin{array}{c}\mathrm{TC} \# 6 \\
{ }^{\circ} \mathrm{C}\end{array}$ & $\begin{array}{c}\mathrm{TC} \# 7 \\
{ }^{\circ} \mathrm{C}\end{array}$ & $\begin{array}{l}\mathrm{TC} \# 8 \\
{ }^{\circ} \mathrm{C}\end{array}$ & $\begin{array}{c}\mathrm{TC} \# 9 \\
{ }^{\circ} \mathrm{C}\end{array}$ & $\begin{array}{c}\mathrm{TC} \# 10 \\
{ }^{\circ} \mathrm{C}\end{array}$ & $\begin{array}{c}\text { Average } \\
{ }^{\circ} \mathrm{C}\end{array}$ & $\underset{{ }^{\circ} \mathrm{C}}{\text { Average } \Delta \mathrm{T}}$ & $\begin{array}{l}\text { Maximum Level } \\
(\text { SNI } 1741-2008)\end{array}$ \\
\hline 0 & 23.5 & 22.5 & 23.2 & 22.8 & 22.7 & 22.9 & 0.0 & 180 \\
\hline 10 & 23.6 & 22.6 & 23.2 & 22.9 & 22.7 & 23.0 & 0.1 & 180 \\
\hline 20 & 24.6 & 23.1 & 23.4 & 23.0 & 22.7 & 23.4 & 0.4 & 180 \\
\hline 30 & 28.3 & 28.1 & 25.0 & 24.3 & 27.2 & 26.6 & 3.6 & 180 \\
\hline 40 & 38.6 & 38.0 & 31.5 & 31.7 & 38.6 & 35.7 & 12.7 & 180 \\
\hline 50 & 53.5 & 50.2 & 43.8 & 42.0 & 53.0 & 48.5 & 25.6 & 180 \\
\hline 60 & 75.3 & 60.4 & 65.5 & 62.0 & 70.7 & 66.8 & 43.8 & 180 \\
\hline 70 & 81.7 & 62.7 & 72.2 & 70.4 & 74.5 & 72.3 & 49.4 & 180 \\
\hline 80 & 83.8 & 65.1 & 75.6 & 77.0 & 77.1 & 75.7 & 52.8 & 180 \\
\hline 90 & 86.7 & 65.9 & 78.8 & 80.4 & 79.3 & 78.2 & 55.3 & 180 \\
\hline 100 & 88.1 & 67.2 & 79.7 & 84.1 & 79.0 & 79.6 & 56.7 & 180 \\
\hline 110 & 90.4 & 68.2 & 81.9 & 80.6 & 79.9 & 80.2 & 57.3 & 180 \\
\hline 120 & 90.7 & 68.9 & 82.8 & 88.1 & 81.0 & 82.3 & 59.4 & 180 \\
\hline 130 & 92.2 & 70.0 & 84.3 & 89.7 & 81.2 & 83.5 & 60.5 & 180 \\
\hline 140 & 97.8 & 69.9 & 86.1 & 89.7 & 82.1 & 85.1 & 62.2 & 180 \\
\hline 150 & 93.8 & 70.4 & 86.9 & 91.4 & 82.1 & 84.9 & 62.0 & 180 \\
\hline 160 & 94.5 & 71.0 & 87.9 & 92.6 & 82.2 & 85.6 & 62.7 & 180 \\
\hline 170 & 94.8 & 71.3 & 88.8 & 93.4 & 82.2 & 86.1 & 63.2 & 180 \\
\hline
\end{tabular}




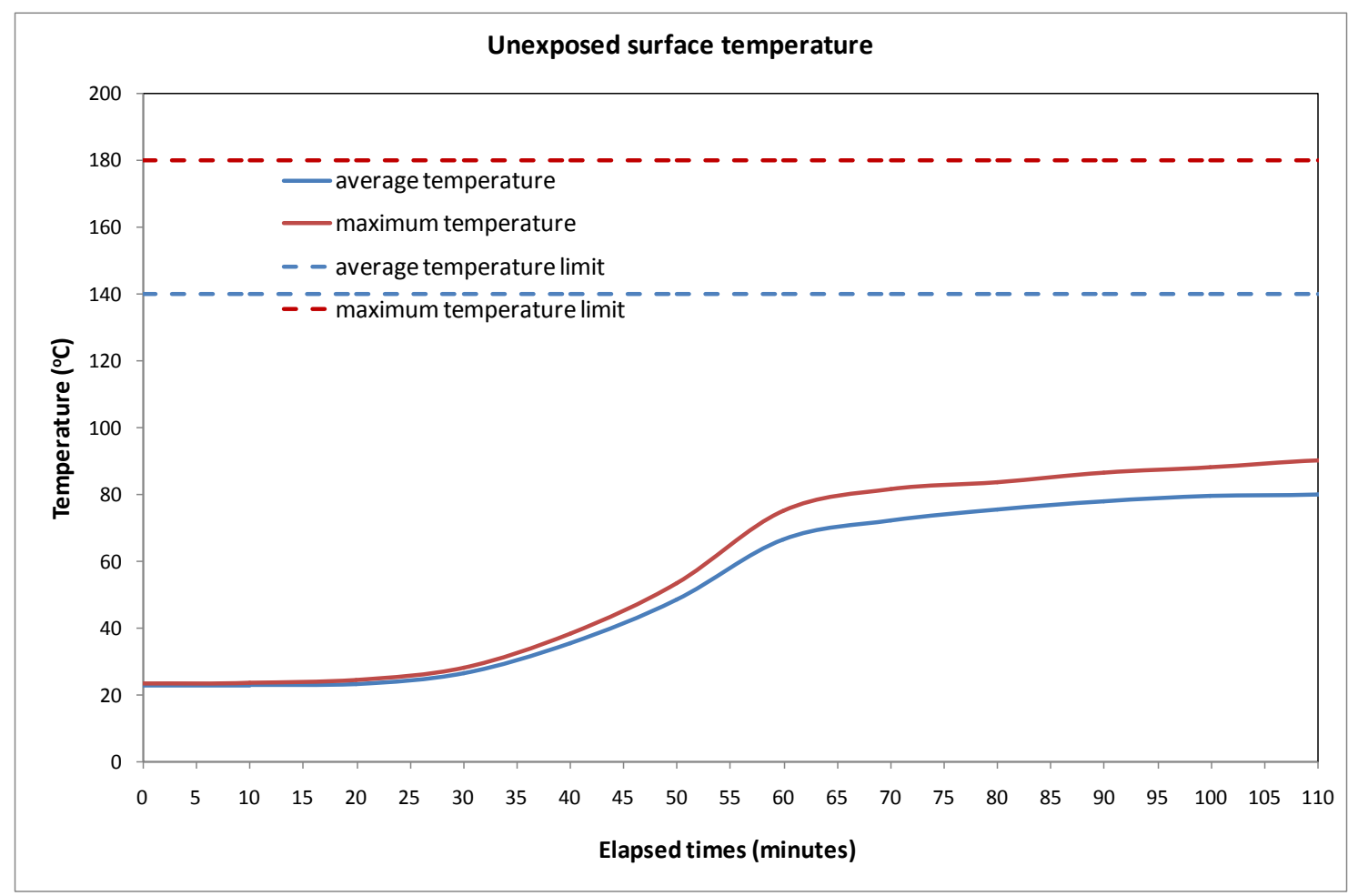

Graph 2

Construction work of sample was conduct in laboratory and then put up the thermocouple for measure sample surface temperature.

Sample that was tested is red bricks sized $200 \mathrm{~mm}$ x $100 \mathrm{~mm}$ x $50 \mathrm{~mm}$. Red brick was glued between one and another using mortar mixture until become wall with total dimension : length $2640 \mathrm{~mm} \mathrm{x}$ width $2640 \mathrm{~mm} \times$ thick $100 \mathrm{~mm}$. Laboratory did not conduct verification mortar quality that was used.

Ambient air temperature at the beginning of testing is $24.9^{\circ} \mathrm{C}$.

Furnace temperature was arranged so follows standard curve time - temperature according to SNI (Standard National Indonesia) 1741 - 2008.
Furnace temperature were measured by nine thermocouple TC \#1 - TC \#9 that separated in furnace.

Unexposed surface temperature of sample were measured by nine thermocouple TC\#10 - TC\#18 that put up exact way at wall surface of sample that unexposed by fire.

Fire test was conduct as long as 90 minute.

Average furnace temperature was showed at Table 3 and Graph 3.

At the end of test, average furnace temperature achieved $975^{\circ} \mathrm{C}$. 
Table 3. Average Furnace Temperature

\begin{tabular}{ccc}
\hline Minute & $\begin{array}{c}\text { Average Furnace Temperature } \\
{ }^{\circ} \mathrm{C}\end{array}$ & $\begin{array}{c}\text { Standard Furnace Temperature } \\
\text { SNI } 1741-2008\end{array}$ \\
\hline 0 & 29 & 20 \\
10 & 631 & 678 \\
20 & 783 & 781 \\
30 & 844 & 842 \\
40 & 889 & 885 \\
50 & 926 & 918 \\
60 & 935 & 945 \\
70 & 946 & 968 \\
80 & 957 & 988 \\
90 & 975 & 1006 \\
\hline
\end{tabular}

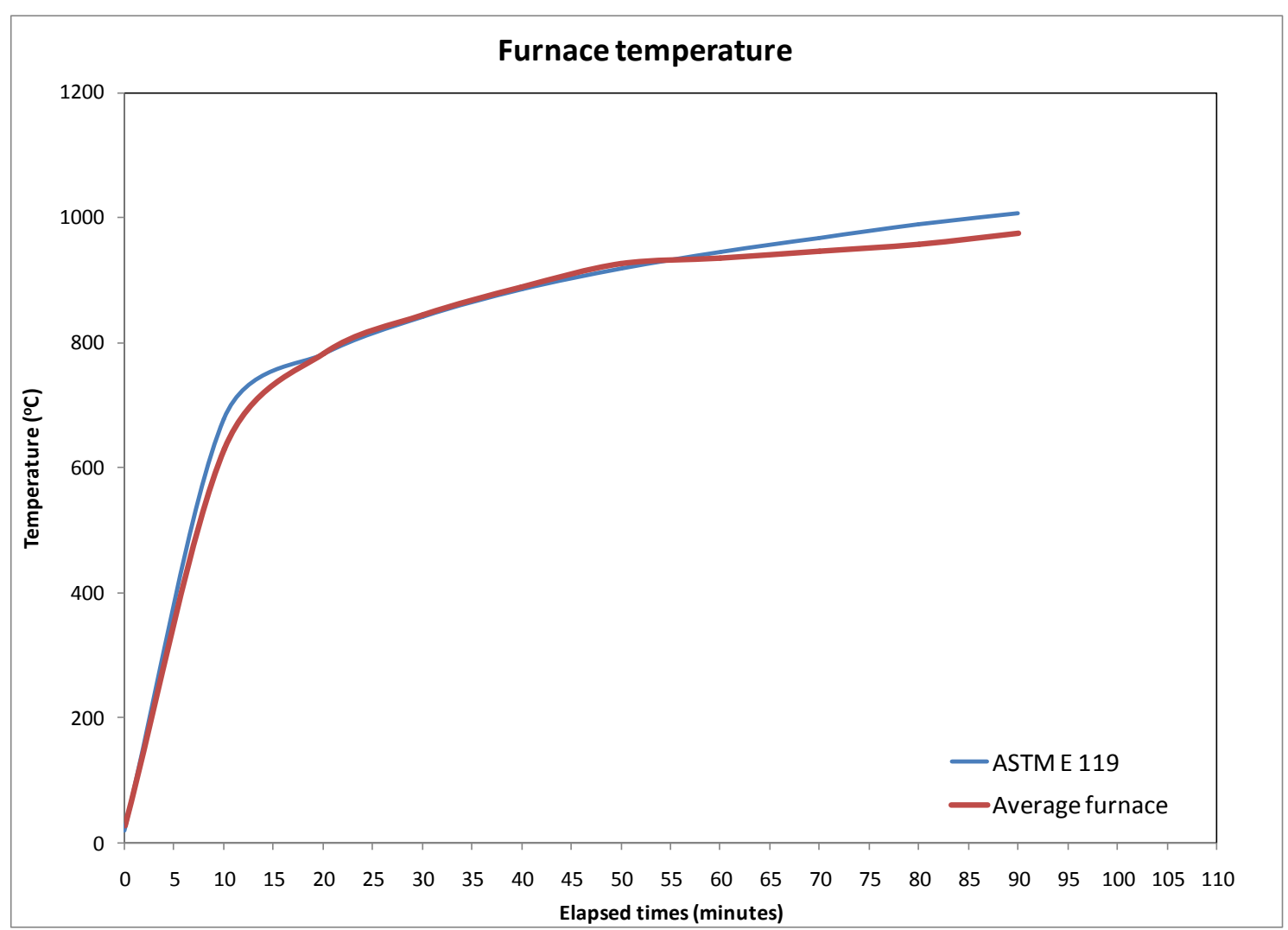

Graph 3 Unexposed surface temperature was showed at Table 4 and Graph 4. 
Table 4. Temperature at Surface Sample

\begin{tabular}{ccccccccc}
\hline Minute & $\begin{array}{c}\mathrm{TC} \# 6 \\
{ }^{\circ} \mathrm{C}\end{array}$ & $\begin{array}{c}\mathrm{TC} \# 7 \\
{ }^{\circ} \mathrm{C}\end{array}$ & $\begin{array}{c}\mathrm{TC} \# 8 \\
{ }^{\circ} \mathrm{C}\end{array}$ & $\begin{array}{c}\mathrm{TC} \# 9 \\
{ }^{\circ} \mathrm{C}\end{array}$ & $\begin{array}{c}\mathrm{TC} \# 10 \\
{ }^{\circ} \mathrm{C}\end{array}$ & $\begin{array}{c}\text { Average } \\
{ }^{\circ} \mathrm{C}\end{array}$ & $\begin{array}{c}\text { Average } \Delta \mathrm{T} \\
{ }^{\circ} \mathrm{C}\end{array}$ & $\begin{array}{c}\text { Maximum Level } \\
(\text { SNI 1741 - 2008) }\end{array}$ \\
\hline 0 & 24.6 & 23.8 & 24.4 & 24.3 & 24.0 & 24.2 & 0.0 & 180 \\
10 & 23.8 & 24.7 & 24.2 & 23.6 & 24.7 & 24.2 & 0.0 & 180 \\
20 & 24.4 & 24.7 & 24.7 & 24.2 & 24.8 & 24.6 & 0.3 & 180 \\
30 & 26.8 & 28.2 & 25.0 & 28.5 & 26.7 & 27.0 & 2.8 & 180 \\
40 & 34.7 & 42.5 & 31.0 & 41.3 & 40.6 & 38.0 & 13.8 & 180 \\
50 & 48.0 & 80.1 & 48.0 & 62.9 & 74.9 & 62.8 & 38.6 & 180 \\
60 & 66.1 & 95.6 & 76.8 & 86.1 & 90.6 & 83.0 & 58.8 & 180 \\
70 & 81.0 & 95.8 & 86.9 & 83.8 & 92.3 & 88.0 & 63.7 & 180 \\
80 & 90.0 & 95.8 & 90.3 & 84.2 & 92.4 & 90.5 & 66.3 & 180 \\
90 & 93.1 & 95.4 & 91.7 & 85.2 & 92.6 & 91.6 & 67.4 & 180
\end{tabular}

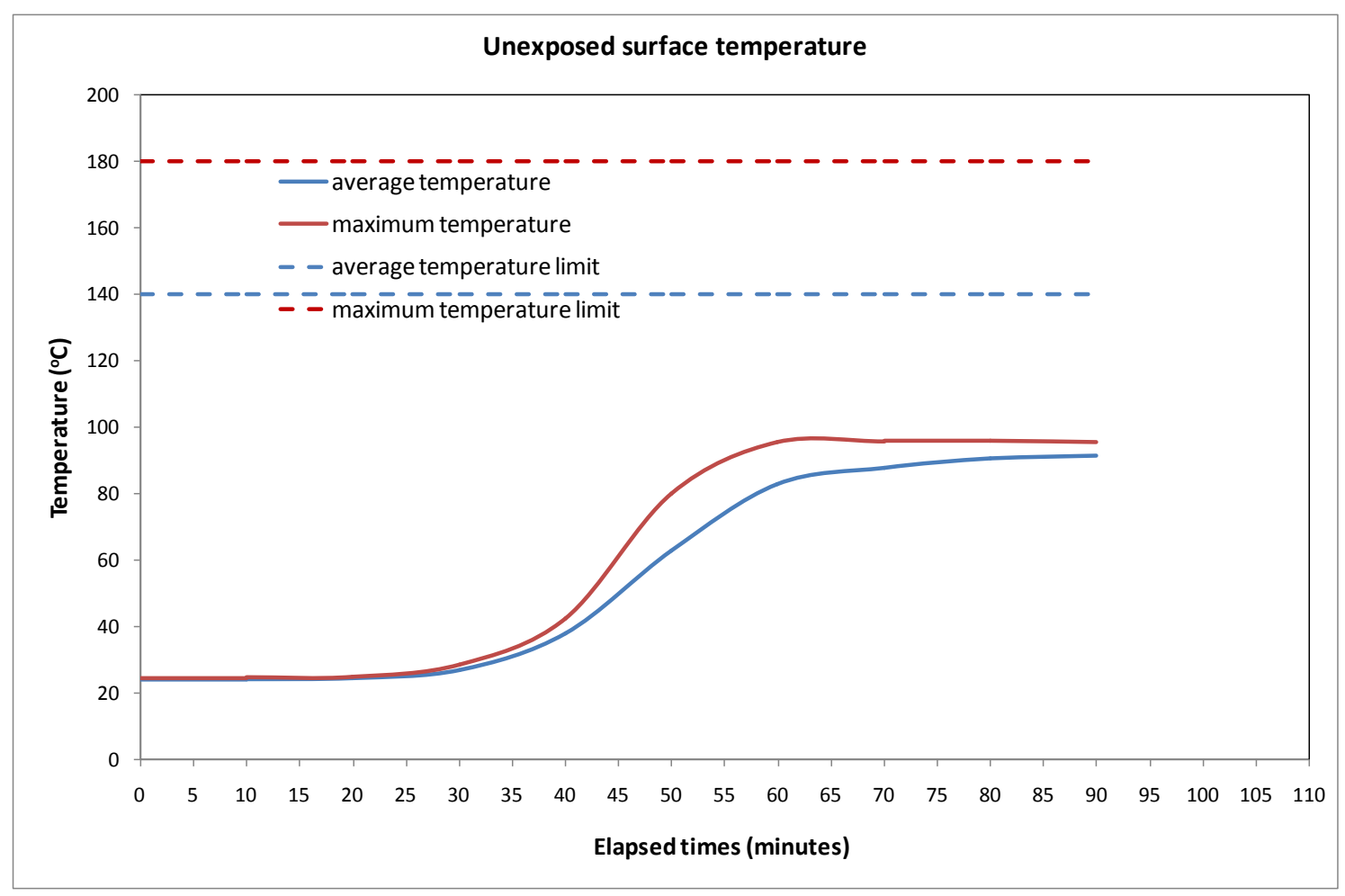

Graph 4

\section{ANALYSIS AND DISCUSSION}

Building component is a part of housing and building, both bearer load and not bearer load (wall, column, wall partition, beam, floor, and roof).

Fire resistance of building component is characteristics of the building component to fire resistance, without loosing the function as structure that expressed in time $1 / 2$ hour, 1 hour, 2 hour, and 3 hour.
Building material is all sorts of material worn on or for construction housing and building, either as material layer covering inside building (finishing material for interior) or material form of building components. Building material may consist of one kind of material or combination some kinds of material that shaped. Materials interior that cannot be moved as : closet cropping, carpet, curtains, furnishing household supersized and so on, that is contents of the building, include in this sense. 
Fire resistance of building component, both non structural and structural, fulfill requirements Standard National Indonesia (SNI) 1741-2008 "Test Method Fire Resistance Component Structure Building for Prevention Fire Hazard on Housing and Building".

Based on their characteristics when fire tested (burning characteristics), building material classified in 5 (five) level quality, namely level quality 1 (M1), level quality 2 (M2), level quality 3 (M3), level quality 4 (M4) and level quality 5 (M5). M1 is non combustible material and M5 is combustible material.

Material level quality 1 (M1) to be able to comply with the requirements material M1 must be able to meet the requirements of fire test on surface, if : when testing, the temperature in furnace increase not more $50{ }^{\circ} \mathrm{C}$.

Material level quality 5 (M5) is all materials are not able to meet the requirements of fire test on surface, or materials not able to meet the requirements of material $\mathrm{M} 4$.

Based on fire resistance, building components can be divided into five classes as follows :

- $\quad$ fire resistance 3 hour, that is main building component that resistant to fire at least 3 hour.

- $\quad$ fire resistance 2 hour, that is main building component that resistant to fire at least 2 hour.

- fire resistance 1 hour, that is main building component that resistant to fire at least 1 hour.

- fire resistance $1 / 2$ hour, that is main building component that resistant to fire at least $1 / 2$ hour.

- Specific fire resistance, that is main building component which is not covered in $3,2,1$ and $1 / 2$ hours, and not arranged in

this provision, but

organized specifically.

Building component bearer load, should fulfill the requirements :

- Material to main building component like outer wall, column, and beams should meet the requirements of material M1.

- $\quad$ Material to main building component like inside wall should meet the requirements of material M1 or M2.

- Material covering roof and floor should meet the requirements of material M1 or M2.

Testing results fire resistance level of building component, expressed with time unit in minutes, as follows :

- $\quad$ Stability, limit in which building component suffer destruction (collapse), means that component can not functioned bearer load.

- Integrity, limit in which building component that functioned as fire retardant, like wall and floor occur cracks translucent, so fire or smoke can getiing out.

- Insulation, limit in which surface wall or floor that not burned occur average increase temperature no more than $180{ }^{\circ} \mathrm{C}$, or one of thermocouple surface unexposed fire no more than $220^{\circ} \mathrm{C}$.

Outer side wall of building should have fire resistance not less than 0.5 hours, but not applied to outer side wall that not bearer load. 
Wall partition should have fire resistance not less than 1 hour, but not applied to wall partition between buildings that not divided into compartments.

Joint wall partition with outer side wall : if wall partition connect with outer side wall, then outer

Table 5. Classification Characteristic Material

\begin{tabular}{|c|c|c|c|c|c|c|}
\hline \multirow[t]{2}{*}{ Testing } & \multirow[t]{2}{*}{ Observation } & \multirow{2}{*}{$\begin{array}{l}\text { Non Combustible Material } \\
\text { M1 }\end{array}$} & \multicolumn{4}{|c|}{ Combustible Material } \\
\hline & & & $\begin{array}{l}\text { Difficult to } \\
\text { Burn M2 }\end{array}$ & $\begin{array}{c}\text { Fire } \\
\text { Retards } \\
\text { M3 }\end{array}$ & $\begin{array}{l}\text { Little } \\
\text { Retards } \\
\text { M4 }\end{array}$ & $\begin{array}{c}\text { Flammable } \\
\text { M5 }\end{array}$ \\
\hline Fire & $\begin{array}{l}\text { Temperature } \\
\text { increase in } \\
\text { furnace }\end{array}$ & $\begin{array}{l}\text { Temperature increase } \leq 50{ }^{\circ} \mathrm{C} \\
\text { and inside furnace does not } \\
\text { occur a continuous flame for } 10 \\
\text { seconds or more. }\end{array}$ & \multicolumn{4}{|c|}{ Temperature increase in furnace above $50{ }^{\circ} \mathrm{C}$} \\
\hline
\end{tabular}

Table 6. Classification Quality Material

\begin{tabular}{|c|c|c|c|}
\hline Kinds of Material & Description & Usage & $\begin{array}{l}\text { Level } \\
\text { Quality }\end{array}$ \\
\hline Mortar & $\begin{array}{l}\text { Composition : } \\
1 / 2-1 / 4 \text { portland cement }(\mathrm{PC}): 1 \text { lime }: 5 \\
\text { trass }\end{array}$ & $\begin{array}{l}\text { Masonry red bricks, } \\
\text { conblock, hollow brick }\end{array}$ & M1 \\
\hline $\begin{array}{l}\text { Mortar plaster } \\
\text { cast }\end{array}$ & $\begin{array}{l}\text { Containing } 66 \% \text { heavy compound of } \\
\text { calcium sulphate }\left(\mathrm{CaSO}_{4}, 1 / 2 \mathrm{H}_{2} \mathrm{O}\right)\end{array}$ & $\begin{array}{l}\text { For plastering, as protector } \\
\text { of columns and beams }\end{array}$ & M1 \\
\hline Red brick & $\begin{array}{l}\text { Length } 200 \mathrm{~mm} \text {; width } 100 \mathrm{~mm} \text {; thick } 5 \\
\mathrm{~mm}\end{array}$ & $\begin{array}{l}\text { Wall bearer, wall not } \\
\text { bearer, outside wall, fence }\end{array}$ & M1 \\
\hline $\begin{array}{l}\text { Lightweight } \\
\text { concrete block } \\
\text { (aerated concrete } \\
\text { block) }\end{array}$ & 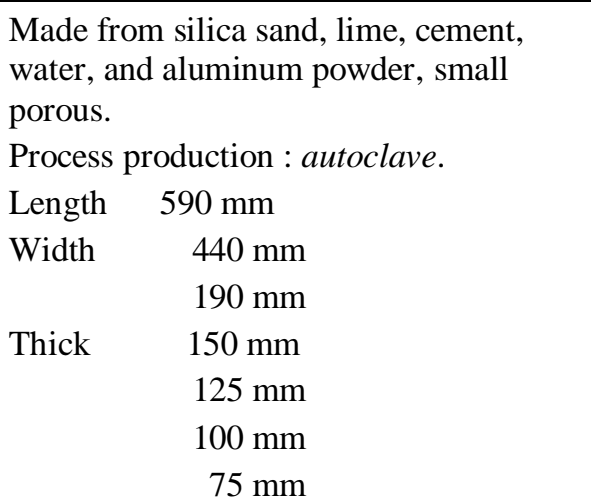 & $\begin{array}{l}\text { Wall not bearer load and } \\
\text { wall partition. }\end{array}$ & M1 \\
\hline
\end{tabular}


Table 7. Classification Fire Resistance Building Component

\begin{tabular}{|c|c|c|c|}
\hline Kinds of Material & Description & Usage & $\begin{array}{l}\text { Resistance } \\
\text { Level }\end{array}$ \\
\hline Red brick panel & 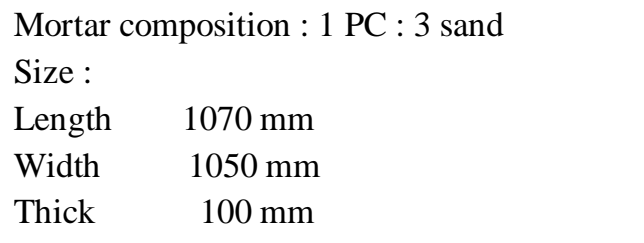 & $\begin{array}{l}\text { For outside wall and inside } \\
\text { wall (not bearer load) }\end{array}$ & $>3$ hours \\
\hline $\begin{array}{l}\text { Lightweight concrete } \\
\text { block (aerated concrete } \\
\text { block) }\end{array}$ & $\begin{array}{l}\text { Made from silica sand, lime, cement, and } \\
\text { aluminum powder. } \\
\text { Small porous on surface, process production } \\
\text { : autoclave. } \\
\text { Mortar composition for space : } 1 \mathrm{PC}: 3 \text { sand } \\
\text { Size of panel : } \\
\text { Length } \quad 1070 \mathrm{~mm} \\
\text { Width } \quad 1050 \mathrm{~mm} \\
\text { Thick } \quad 100 \mathrm{~mm}\end{array}$ & $\begin{array}{l}\text { For outside wall and wall } \\
\text { partition not bearer load }\end{array}$ & 3 hours \\
\hline
\end{tabular}

\section{CONCLUSION}

Sample lightweight brick have dimension : length $600 \mathrm{~mm} \mathrm{x}$ width $200 \mathrm{~mm} \mathrm{x}$ thick $100 \mathrm{~mm}$, construction wall lightweight brick have dimension : width $1050 \mathrm{~mm}$ x length $1060 \mathrm{~mm}$ x thick 100 $\mathrm{mm}$ meet the requirements of fire resistance level $/ 170 / 170$ according to SNI 1741-2008. That is stability /integrity /insulation.

Stability : it is not required for non structural components. Integrity : does not occur crack translucent so smoke /fire did not get out as long as 170 minutes. Insulation : as long as 170 minutes, increase temperature maximum at one thermocouple on surface unexposed fire, no more than $180{ }^{\circ} \mathrm{C}$; or increase temperature average no more than $180{ }^{\circ} \mathrm{C}$.

Sample test wall red brick thick $100 \mathrm{~mm}$ without plastering meet the requirements of fire resistance level - /90 /90 according to SNI 1741-2008.

Lightweight brick have weight lightly but require expensive material, while red brick have weight more heavy but cheaper in cost construction. So can concluded that if want cheaper building construction (house) suggested to wear red brick, because it can diminish the expense to construction masonry wall. While for project construction highrise building advised to wear lightweight brick as masonry wall, because it is light, can reduce the burden of building construction, so can diminish the expense incurred to building construction.

Each material have advantages and disadvantages. Red brick heavy enough so indirectly affect load factor of building structure. While lightweight brick have advantages : the construction more neat and precision, not require much mortar to space between, but the price more expensive compare with red brick.

\section{REFERENCES}

[Google.com], Disadvantages Building Material Conventional, Date of access: 20/08.2014.

[Google.com], 2014, Lightweight Brick, From Wikipedia Indonesian Language, Free Encyclopedia, Date of access: 20/08.2014.

[Google.com], Yogo Prihatono, Choose Between Red Brick, Conblock, or Lightweight Brick Hebel, Date of access: 20.08.2014. 
[Standard National Indonesia], 1987, Guidance Planning Component Structure Building for Prevention Fire Hazard at Housing and Building, Public Works Department, SKBI : 2.3.53.1987, UDC : 699.81:624.04.
[Standard National Indonesia], 1987, Guidance Testing Fire Resistance Building Structure Component for Prevention Fire Hazard at Housing and Building, Public Works Department, SKBI : 3.2.53.1987, UDC : 699.81:614.84.001.4.

[Standard National Indonesia], 1987, Specification Building Material for Prevention Fire Hazard at Housing and Building, SKBI : 4.4.53.1987, UDC : 699.81.891.004.1. 